\title{
Influence of Hydrogen on the Fermentation in Rumen Protozoa, Entodinium Species
}

Tsuneo Hino

\author{
Department of Agricultural Chemistry, Faculty of Agriculture,
} The University of Tokyo, Bunkyo-ku, Tokyo 113

(Received September 17, 1982)

\begin{abstract}
The influence of $\mathrm{H}_{2}$ on the fermentation of starch by rumen protozoa, mixture of Entodinium species, was studied in cultures in vitro. An experiment in which $\mathrm{H}_{2}$ was continuously flown into cultures to provide the high partial pressure of $\mathrm{H}_{2}$, showed that the fermentation activity of entodinia is lowered by $\mathrm{H}_{2}$ : Starch consumption and organic acid production were decreased. Simultaneously, a shift in the pattern of fermentation products was observed; acetate was decreased greatly, while butyrate was altered little, resulting in the decreased percentage of acetate and increased percentage of butyrate. In another experiment the co-existence of methanogenic bacteria, which were co-cultured to remove $\mathrm{H}_{2}$ produced by entodinia, was found to enhance the fermentation activity of entodinia: Starch consumption, together with organic acid production, were increased. A great increase in acetate and little change in butyrate were also seen. Enhancement of $\mathrm{H}_{2}$ production was shown, which could possibly be the reason for stimulated acetate production. A marked increase in the assumed ATP yield from fermentation was also noted. However, on the whole, the influence of the partial pressure of $\mathrm{H}_{2}$ was not so great as expected. Implications of these results are discussed in detail.

Jpn. J. Zootech. Sci., 54 (5): 320-328, 1983
\end{abstract}

In order to understand the role played by protozoa in the metabolism that occurs in the rumen, expecially in energy metabolism, i.e., the energetic aspect of microbial cell synthesis and volatile fatty acid production, it may be of importance to have basic knowledge and adequate information on the fermentation process and growth rate of protozoa, and the factors affecting them.

In anaerobic organisms and facultative microbes growing anaerobically, it is generally believed that the rate of growth is primarily limited by the fermentation process, i.e., the process of obtaining energy by means of oxidizing substrates ${ }^{1)}$. In these organisms, fermentation activity is decisively affected by the readiness to dispose of electrons liberated from substrate oxidation. One of the most important modes of disposing of excess electrons has been known to be the formation of $\mathrm{H}_{2}$ : Hydrogen is a common end product of carbohydrate fermentation in many bacterial ${ }^{2,3}$ and several protozoal ${ }^{4-6)}$ species, including rumen microbes ${ }^{7}$.

Some different mechanisms by which $\mathrm{H}_{2}$ is formed have been known in different types of organisms, and the enzyme hydrogenase, which catalyzes $\mathrm{H}_{2}$ formation, has been at least partially characterized in several species ${ }^{3,8-10}$. In several bacterial species, it has been shown that $\mathrm{H}_{2}$ production is influenced by the partial pressure of $\mathrm{H}_{2}$, and stimulated by growth with $\mathrm{H}_{2}$-consuming organisms ${ }^{2,11}$. Furthermore, in 
several species of $\mathrm{H}_{2}$-producing rumen bacteria, the shift in the pattern of fermentation by co-existence of a $\mathrm{H}_{2}$-consuming organism has been demonstrated ${ }^{12-15}$. Recently, a new example of intermicrobial $\mathrm{H}_{2}$ transfer has been reported ${ }^{16)}$ : A rumen anaerobic fungus, which is an eukaryote, shifts the pattern of fermentation, when cocultured with methanogens. The importance of the intermicrobial transfer of $\mathrm{H}_{2}$ has been emphasized in relation to the fermentation in the rumen ${ }^{11-10)}$.

Rumen protozoa form $\mathrm{H}_{2}$ as a major 'electron sink product', a product formed by accepting electrons? : Hydrogen formation is a substantial way of disposing of excess electrons. Whether this mechanism functions smoothly or not might greatly influence the fermentation activity, and consequently the growth rate.

Recently, VoGELs et al. have reported the close association of methanogenic bacteria with rumen entodiniomorphid protozoa, and have suggested that this enables an effective intermicrobial $\mathrm{H}_{2}$ transfer by which both can grow faster ${ }^{17}$.

This paper reports the influence of $\mathrm{H}_{2}$ on the fermentation in Entodinium species: In Experiment 1, the influence of $\mathrm{H}_{2}$ flown into the cultures to provide the high partial pressure of $\mathrm{H}_{2}$ was examined, being compared with the control in which $\mathrm{N}_{2}$ was flown. In Experiment 2, the effect of methanogenic bacteria, which were co-cultured to remove $\mathrm{H}_{2}$ produced by the protozoa, was investigated.

\section{Materials and Methods}

1. Collection and preparation of entodinia.

A Japanese native goat ( $c a .25 \mathrm{~kg}$ ) fitted with a permanent rumen cannula was used to collect protozoa. In order to obtain only Entodinium species, all other types of protozoa were removed from the rumen as follows: The goat was starved for 2 days, and then fed only commercial formula feed for cows for 5 days. During these 5 days $500 \mathrm{ml} /$ day of $1 \%$ dioctyl sodium sulphosuccinate solution ${ }^{18,19)}$ was administered into the rumen through a cannula. At the end of this purification period, only entodinia were detected in an extremely small number. Subsequently, diet was changed to a normal one consisting of alfalfa hay, green forage, and formula feed. Only entodinia, mainly E.caudatum, E. simplex, and E.longinucleatum, were seen to increase to a normal population density $\left(\mathrm{ca} .10^{6} / \mathrm{ml}\right.$ ) in 2 weeks. These protozoa were collected and prepared as described previously ${ }^{20)}$.

2. Procedures and conditions of the culture of entodinia.

To prevent the contaminating bacteria from proliferating, washed protozoa were preincubated in buffered saline ${ }^{21}$ for $16 \mathrm{hr}$ with a high concentration of antibiotics; $2,000 \mathrm{U} / \mathrm{ml}$ of penicillin $\mathrm{G}, 200 \mu \mathrm{g} / \mathrm{ml}$ each of aminobenzylpenicillin, cephaloridin, streptomycin, and kanamycin.

In Experiment 1, these protozoa were cultured for $48 \mathrm{hr}$ with $500 \mathrm{U} / \mathrm{ml}$ of penicillin $\mathrm{G}$ and $50 \mu \mathrm{g} / \mathrm{ml}$ of cephaloridin, both of which can be considered to have no harmful effect on protozoa directly. Incubation was carried out under continuous bubbling with $\mathrm{H}_{2}$ or $\mathrm{N}_{2}$ using an apparatus illustrated in Fig. 1. In Experiment 2, protozoa treated as above were cultured for $48 \mathrm{hr}$ with or without methanogenic 


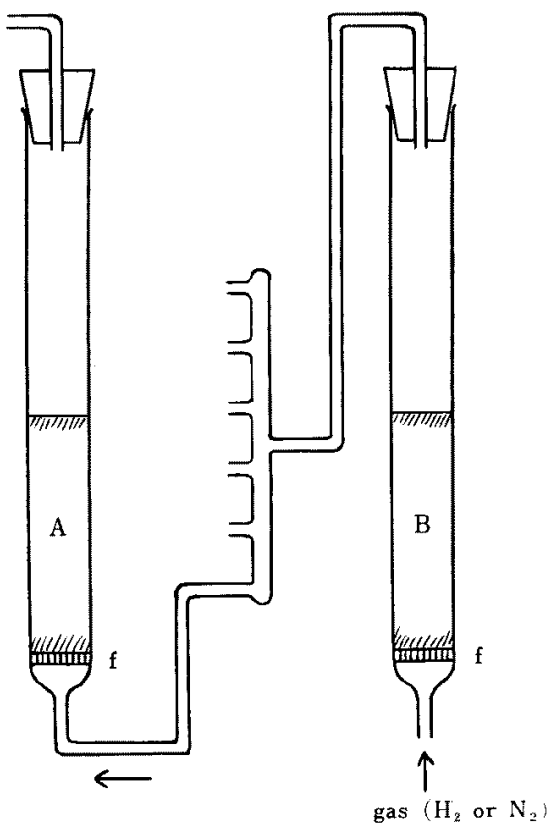

Fig. 1. Apparatus for the culture of entodinia used in Experiment 1. A: culture fluid $(100 \mathrm{ml})$, B: $5 \%$ pyrogallol in $10 \% \mathrm{Na}_{2} \mathrm{CO}_{3}, \mathrm{f}$ : glass filter.

bacteria. Culturing was done shaking slowly in $300 \mathrm{~m} \iota$ round-bottom flasks containing $100 \mathrm{ml}$ of culture fluid. Initial gas phase was $\mathrm{O}_{2}$-free $\mathrm{N}_{2}$. The method of collecting the gas produced, and other basic culture conditions have been described previously ${ }^{22}$. Entodinia inoculated in both experiments were approximately $2 \times 10^{4} / \mathrm{m} l$ of culture fluid, and the initial number of methanogenic bacteria was nearly $10^{8} / \mathrm{m} l$ of culture fluid.

3. Media used for the culture of entodinia.

The media used in Experiments 1 and 2 are shown in Table 1. Extracts of rumen bacteria were prepared as follows: One packed cell volume of mixed bacteria collected from the rumen was suspended in 4 volumes of buffered saline, and disrupted by ultra-sonication $\left(2 \sim 3^{\circ} \mathrm{C}, 3 \mathrm{~min}\right)$. The homogenate was then centrifuged $(20,000 \mathrm{~g}$,

Table 1. Composition of the culture media for entodinia

\begin{tabular}{lcc}
\hline \hline & Medium 1 & Medium 2 \\
\hline Buffered saline & $85 \mathrm{~m} l$ & $55 \mathrm{~m} l$ \\
Extracts of rumen bacteria & $5 \mathrm{~m} l$ & $5 \mathrm{~m} l$ \\
Suspension of heated $E$. coli & $5 \mathrm{~m} l$ & $5 \mathrm{~m} l$ \\
Trace mineral and vitamin solution & $5 \mathrm{~m} l$ & $5 \mathrm{~m} l$ \\
Methanogen cell suspension & & $30 \mathrm{~m} l$ \\
Starch particles with $0.1 \% \beta$-sitosterol & $0.5 \mathrm{~g}$ & $0.5 \mathrm{~g}$
\end{tabular}


$15 \mathrm{~min}$ ), and the supernatant was filtered through membrane filter (pore size, $0.45 \mu$ ). The filtrate, which was stored at $-80^{\circ} \mathrm{C}$ until needed, was used as the extracts. Escherichia coli cultured in nutrient broth ${ }^{28)}$ and harvested at full growth was used as a protein source, after being heated at $80^{\circ} \mathrm{C}$ for $10 \mathrm{~min}$. Beta-sitosterol which had been adsorbed to starch particles ${ }^{24)}$ was added to the media. Trace mineral and vitamin solution has already been reported ${ }^{25)}$. Methanogen cell suspensions were prepared as described below. Intact cells were used for co-cultures, and the heated $\left(80^{\circ} \mathrm{C}, 10 \mathrm{~min}\right)$ ones were used for control, i.e., mono-cultures.

4. Sources and culture of methanogenic bacteria.

Methanobrevibacterium ruminantium was kindly supplied by Dr. M. P. BRYANT, Department of Dairy Science, University of Illinois, and Methanobacterium formicium was generously given by the Laboratory of Microbiology and Fermentation, this department.

These bacteria were grown under $\mathrm{O}_{2}$-free $\mathrm{H}_{2}-\mathrm{CO}_{2}(80: 20)$ gas mixture in $30 \mathrm{ml}$ of medium using butylrubber double-capped bottles $(100 \mathrm{ml})$. The medium used for the culture of M.ruminantium was prepared according to SCHEIFINGER et al. ${ }^{13)}$ and LATHAM and WoLIN ${ }^{14}$ ), slightly modified to consist of: Trypticase (BBL), $2 \mathrm{~g}$; yeast extract (Difco), $2 \mathrm{~g}$; Na-formate, $0.1 \mathrm{~g}$; Na-acetate, $0.5 \mathrm{~g}$; buffered saline, $200 \mathrm{~m} l$; clarified rumen fluid, $400 \mathrm{ml} ; \mathrm{H}_{2} \mathrm{O}, 400 \mathrm{ml}$; cysteine- $\mathrm{HCl}, 0.5 \mathrm{~g}$; and resazurin, $1 \mathrm{mg}$. Ten percent $\mathrm{Na}_{2} \mathrm{CO}_{3}$ solution was added to adjust the $\mathrm{pH}$ to 7.0. The medium for M. formicium was essentially the same as 'Medium 1' described by BALCH et al. ${ }^{25}$.

The culture mixture of each methanogen at its maximum growth was directly added to the culture medium for entodinia.

5. Analytical methods.

Formate and L-lactate were determined by the formate dehydrogenase ${ }^{36)}$ and the lactate dehydrogenase ${ }^{27}$ methods, respectively. Acetate, propionate, and butyrate were determined by gas chromatography (GC) as described previously ${ }^{22}$. These organic acids were determined before and after incubation, and the difference between the two values of each acid was assumed to be the quantity produced.

Gas analysis was carried out by $\mathrm{GC}$ to measure $\mathrm{H}_{2}$ and $\mathrm{CH}_{4}$ produced, using $\mathrm{C}_{2} \mathrm{H}_{6}$ as an internal standard: At the end of incubation an aliquot of $\mathrm{C}_{2} \mathrm{H}_{6}$ was injected into the culture vessels, and after being thoroughly mixed ${ }^{22)}$, an aliquot of the gas mixture was taken as a sample. GC was conducted at $30^{\circ} \mathrm{C}$, using $\mathrm{CO}_{2}$ as a carrier gas ${ }^{22}$.

Starch was determined as follows: Aliquots of the culture mixture, both before and after incubation, were taken and centrifuged $(500 \mathrm{~g}, 5 \mathrm{~min})$. The precipitate including starch particles and protozoal cells was hydrolyzed with $1 \mathrm{~N} \mathrm{HCl}\left(90^{\circ} \mathrm{C}, 2\right.$ $\mathrm{hr}$ ), and the liberated glucose was determined by the glucose oxidase $\operatorname{method}^{28}$.

The recovery of metabolic hydrogen, and the quantities of fermented hexose and ATP yield were calculated according to the procedures and assumptions described previously ${ }^{22)}$.

\section{Results}

1) Influence of the high partial pressure of $\mathrm{H}_{2}$ on the fermentation in entodinia. 
HiNo

Table 2. Fermentation of starch by entodinia under a flow of $\mathrm{H}_{2}$ or $\mathrm{N}_{2}{ }^{\text {a) }}$

\begin{tabular}{lcc}
\hline \hline & $\mathrm{N}_{2}$ & $\mathrm{H}_{2}$ \\
\hline Starch consumed & $\mu$ moles/vessel & $\mu$ moles/vessel \\
Organic acids produced & $376 \pm 12$ & $322 \pm 8^{*}$ \\
$\quad$ Formate & $11 \pm 1(2.2 \pm 0.1)$ & $9 \pm 1(2.0 \pm 0.1)$ \\
Acetate & $274 \pm 12(54.8 \pm 0.9)$ & $212 \pm 8^{*}\left(47.7 \pm 0.4^{* *}\right)$ \\
Propionate & $16 \pm 1(3.2 \pm 0.1)$ & $25 \pm 2^{*}\left(5.5 \pm 0.1^{* *}\right)$ \\
Butyrate & $182 \pm 11(36.1 \pm 0.5)$ & $172 \pm 9\left(38.7 \pm 0.5^{*}\right)$ \\
Lactate & $19 \pm 2(3.8 \pm 0.1)$ & $26 \pm 2\left(5.9 \pm 0.1^{* *}\right)$ \\
Hexose fermented & $338 \pm 11$ & $304 \pm 9$ \\
Assumed ATP yield & $1,165 \pm 27$ & $1,041 \pm 23^{*}$ \\
ATP/hexose & $3.45 \pm 0.03$ & $3.42 \pm 0.02$ \\
\hline
\end{tabular}

a) The figures in the parentheses are percentages of the total amount. (means IS.E., $\mathrm{n}=3$ ) *: $\mathrm{P}<0.05,{ }^{* *}: \mathrm{P}<0.01$ b) Assumed ATP yield/hexose fermented.

The data obtained in Experiment 1 are summarized in Table 2. When entodinia were constantly exposed to $\mathrm{H}_{2}$, starch consumption was found to be slightly but sig nificantly $(\mathrm{P}<0.05)$ lower than when the protozoa were incubated under a flow of $\mathrm{N}_{2}$. The total amount of organic acids produced was smaller, mainly due to the decrease in acetate production. Production of butyrate, another major product, was altered so litte that the percentage of butyrate was shown to have increased.

Calculations based on the product values show that fermented hexose was slightly decreased by bubbling with $\mathrm{H}_{2}$, but this is statistically insignificant $(\mathrm{P}<0.05)$. Assumed ATP yield was significantly $(\mathrm{P}<0.05)$ decreased by $\mathrm{H}_{2}$. No significant difference was shown for ATP yield per fermented hexose.

2) Effect of the co-existence of methanogenic bacteria on the fermentation in entodinia.

Table 3 shows the results of Experiment 2 obtained using M.ruminantium as a $\mathrm{H}_{2}$-consumer. Entodinia in the co-culture consumed significantly $(\mathrm{P}<0.05)$ larger amount of starch. Simultaneously, in the co-culture an obvious increase in the total amount of organic acids was found: Acetate production remarkably increased, while butyrate production did not significantly do so. This caused a decrease in butyrate, expressed as a percentage. Formate was not detected in the co-culture, probably as a result of its consumption by the methanogen. Production of propionate and lactate was lower in the co-culture.

Calculation of the total $\mathrm{H}_{2}$ produced by the protozoa, on the assumption that 1 mole of $\mathrm{CH}_{4}$ is formed from 4 moles of $\mathrm{H}_{2}$, showed that entodinia in the co-culture produced markedly larger amount of $\mathrm{H}_{2}$. Significant increases in fermented hexose $(\mathrm{P}<0.05)$ and assumed ATP yield $(\mathrm{P}<0.01)$ were also shown.

Essentially the same results were obtained when $M$. formicium was used. (The data are omitted.) 
Table 3. Fermentation of starch by entodinia in mono-culture or co-culture with Methanobrevibacterium ruminantium ${ }^{\text {A }}$

\begin{tabular}{|c|c|c|}
\hline & Mono-culture & Co-culture \\
\hline Starch consumed & $\begin{array}{c}\mu \text { moles/vessel } \\
896 \pm 23\end{array}$ & $\begin{array}{c}\mu \text { moles/vessel } \\
1,055 \pm 28^{*}\end{array}$ \\
\hline Organic acids produced & $1,125 \pm 42$ & $1,321 \pm 36^{*}$ \\
\hline Formate & $25 \pm 1(2.2 \pm 0.0)$ & $0 \pm 0(0.0 \pm 0.0)$ \\
\hline Acetate & $463 \pm 29(41.2 \pm 1.1)$ & $662 \pm 34^{* *}\left(50.1 \pm 1.4^{* *}\right)$ \\
\hline Propionate & $31 \pm 2(2.8 \pm 0.1)$ & $16 \pm 2^{* *}\left(1.2 \pm 0.0^{* *}\right)$ \\
\hline Butyrate & $577 \pm 27(51.3 \pm 0.9)$ & $626 \pm 22\left(47.4 \pm 1.0^{*}\right)$ \\
\hline Lactate & $29 \pm 2(2.6 \pm 0.1)$ & $17 \pm 1^{*}\left(1.3 \pm 0.0^{* *}\right)$ \\
\hline Total $\mathrm{H}_{2}$ produced ${ }^{b}$ & $1,795 \pm 46$ & $2,470 \pm 72^{* *}$ \\
\hline $\mathrm{H}_{2}$ & $1,523 \pm 28$ & $38 \pm 4$ \\
\hline $\mathrm{CH}_{4}$ & $68 \pm 4$ & $608 \pm 12$ \\
\hline Metabolic hydrogen recovery (\%) & $93.0 \pm 1.3$ & $97.7 \pm 2.3$ \\
\hline Hexose formented & $839 \pm 18$ & $974 \pm 27^{*}$ \\
\hline Hexose/starch ${ }^{c)}(\%)$ & $93.6 \pm 1.6$ & $92.3 \pm 2.3$ \\
\hline Assumed ATP yield & $2,779 \pm 45$ & $3,267 \pm 59^{* *}$ \\
\hline ATP/hexose & $3.31 \pm 0.01$ & $3.35 \pm 0.02$ \\
\hline
\end{tabular}

a) Expressions are the same as in Table 2. b) Total $\mathrm{H}_{2}=\mathrm{H}_{2}+4 \mathrm{CH}_{4}$. c) Hexose fermented/ starch consumed.

The quantities of fermentation products in the co-culture presented in Table 3 are apparent values that were obtained by ignoring the quantities consumed by the methanogen as its carbon source. For this reason, a supplementary experiment was carried out to roughly estimate the consumption of organic acids by M.ruminantium, based on various postulations: Approximately the same number of this methanogen as used in Experiment 2 was incubated in the medium used for protozoal culture with added organic acids. Postulating that entodinia produce organic acids at a constant rate under the conditions employed, approximately half the values of the products recorded in Experiment 2 were added; acetate, 300 ( $\mu$ moles/vessel); propionate, 10; butyrate, 300; and lactate, 10. Incubation was done under a gas phase of $\mathrm{H}_{2}-\mathrm{CO}_{2}(80: 20)$. The amounts consumed during incubation for $48 \mathrm{hr}$ were; acetate, $52 \pm 4$; propionate, $1 \pm 1$; butyrate, $16 \pm 3$; and lactate, $1 \pm 0$.

If the data in Table 3 are corrected by using these values, the following values can be obtained; acetate, 714 ( $\mu$ moles/vessel); propionate, 17; butyrate, 642; and lactate, 18. Correction for formate is omitted, because this substance could be largely fermented by the methanogen ${ }^{29}$ ), and consequently recovered in $\mathrm{CH}_{4}$. The results of the calculations using these corrected values are; total organic acids, 1,391 $\mu$ moles/ vessel; metabolic hydrogen recovery, 94.4\%; fermented hexose, 1,017 $\mu$ moles/vessel; assumed ATP yield, $3,423 \mu$ moles/vessel and assumed ATP yield/fermented hexose, 3. 37.

Thus, the difference in the values between the mono- and co-cultures is expanded by correcting the actually determined values. In this case, ATP yield per fermented hexose is significantly $(P<0.05)$ higher in the co-culture than the mono-culture, 
which is due to the elevated value of acetate; acetate is a more oxidized substance than other fermentation products.

There may be little solid evidence for these postulations, but it can be certain that the corrected values are closer to the true values than the actually determined ones.

\section{Discussion}

It was shown in Experiment 1 that fermentation activity of entodinia is depressed by the high partial pressure of $\mathrm{H}_{2}$. More marked influence of $\mathrm{H}_{2}$ was seen on the pattern of fermentation products: Acetate was significantly decreased, while the amount of butyrate was not altered. This probably indicates that formation of acetate is regulated in a different manner from that of butyrate, though both are considered to be formed via the same pathway, as far as acetyl-Co A. It has been reported that Trichomonas foetus ${ }^{30)}$ and Dasytricha ruminantium ${ }^{31}$ possess a unique organelle, 'hydrogenosome', in which acetate may be formed. If entodinia also have such an organelle, it may be possible that acetate is formed in this compartment, and butyrate in another one.

The amount of propionate and the percentage of lactate were higher in the culture receiving $\mathrm{H}_{2}$. However, it is not certain whether these trace products, together with formate, were formed by entodinia themselves; it may be possible that contaminating microbes were present in the protozoal culture, in spite of an effort to remove and suppress them. This point was not examined.

The influence of $\mathrm{H}_{2}$, on the whole, was not so great as expected. It may be likely that in the control culture bubbled with $\mathrm{N}_{2}, \mathrm{H}_{2}$ concentration on the surface of protozoal cells was not reduced to the level at which $\mathrm{H}_{2}$ has little influence on the fermentation in entodinia; above a certain level of $\mathrm{H}_{2}$, its inhibitory effects may not greatly differ.

As shown in Experiment 2, in the co-culture where a fairly low partial pressure of $\mathrm{H}_{2}$ is considered to have been maintained, enhancement of acetate production and resultant fermentation activity was more marked. It is probable that this enhancement mainly resulted from the stimulation of $\mathrm{H}_{2}$ production, though other explanations may be possible, i.e., methanogenic bacteria exerted stimulatory effects on the metabolism of entodinia in other unknown manners.

However, again, the effect of the co-existence of methanogenic bacteria was not so great as expected. It has been reported that Selenomonas ruminantium produced approximately 100 times more $\mathrm{H}_{2}$, when co-cultured with a methanogen than in monoculture $^{13)}$. In this ${ }^{15)}$ and other ${ }^{1214)} \mathrm{H}_{2}$-producing bacteria, the shift in the products caused by $\mathrm{H}_{2}$-consuming bacteria was qualitatively and/or quantitatively more drastic than that shown in this study. It is believed that these bacteria have a hydrogenase which catalyzes the formation of $\mathrm{H}_{2}$ from reduced pyridine nucleotide:

$$
\mathrm{NADH}+\mathrm{H}^{+} \rightleftarrows \mathrm{NAD}^{+}+\mathrm{H}_{2}
$$

This reaction is considered to be extremely sensitive to the partial pressure of $\mathrm{H}_{2}$; 
only at extremely low partial pressure of $\mathrm{H}_{2}$ (below $10^{-3} \mathrm{~atm}$ ), the formation of $\mathrm{H}_{2}$ is favored $^{7,32)}$.

No information is available at present on the mechanism of $\mathrm{H}_{2}$ formation in entodinia, but the data obtained in the present study may possibly indicate that the manner of $\mathrm{H}_{2}$ production in entodinia is different from that in the bacteria mentioned above. Recently, an investigation on the mechanism of $\mathrm{H}_{2}$ production in Dasytricha ruminantium has been reported ${ }^{31)}$, indicating that the $\mathrm{H}_{2}$-producing system in this organism is similar to that reported for Trichomonas foetus, which is rather akin to saccharolytic clostridia in respect to $\mathrm{H}_{2}$ formation ${ }^{3,5,6,30)}$.

In conclusion, however, it is evident that the partial pressure of $\mathrm{H}_{2}$ has an influence on the fermentation process of entodinia: Probably, the inhibitory effect of $\mathrm{H}_{2}$ appears to be the end product inhibition that is seen in general. It was also proven that $\mathrm{H}_{2}$ transfer from protozoa to methanogenic bacteria does take place, as suggested by VoGels et al. ${ }^{17}$. As a consequence, entodinia co-cultured with a methanogen ferment carbohydrate at a higher rate, and trap more energy from the substrate. This may presumably suggest that in the presence of $\mathrm{H}_{2}$-consuming organisms, entodinia can grow faster than in their absence.

It seems to be important to take these facts into consideration, when the data obtained with a single or pure culture are generalized, or applied to the real rumen: Probably, such data do not accurately reflect the real state or nature occurring in the rumen that is an extremely complicated ecosystem.

\section{Acknowledgements}

The author is grateful to Prof. M.P.. Bryant, University of Illinois, U. S. A., for the gift of Methanobrevibacterium ruminantium, and also to Prof. H. NAITOH, this laboratory, for supporting this study and providing every facility for it.

\section{References}

1) Thauer, R. K., K. Jungermann, and K. Decker, Bacteriol. Rev., 41: 100-180. 1977.

2) Gest, H., Bacteriol. Rev., 18: 43-73. 1954.

3) GRAY, C. T. and H. Gest, Science, 148: 186-192, 1965.

4) Bragg, P. D. and R. E. Reeves, Exptl. Parasitol., 12: 393-400. 1962.

5) Bauchop, T., J. Gen. Microbiol., 68: 27-33, 1971.

6) Müller, M., Annu. Rev. Microbiol., 29: 467-483. 1975.

7) Hungate, R. E., in The Rumen and Its Microbes, 8-147, Academic Press Inc., New York and London. 1966.

8) Mortenson, L. E., and J. S. Chen, in Microbial Iron Metabolism, A comprehensive treatise. (Neilands, J. B., ed.) 231-282. Academic Press Inc., New York and London. 1974.

9) Reddy, C. A., M. P. Bryant, and M. J. Wolin, J. Bacteriol., 110: 126-132. 1972.

10) Joyner, A. E., W. T. Winter, and D. M. Gobbout, Can. J. Microbiol., 23: 346-353. 1977.

11) Wolin, M. J., in Digestion and Metabolism in the Ruminant (McDonald, I. W. and A.C.I. WARNer, eds.) 134-148. The University of New England Publishing Unit, Australia. 1975.

12) Iannotti, E. L., D. Kafkewitz, M. J. Wolin, and M. P. Bryant, J. Bacteriol., 114: 1231-1240. 1973.

13) Scheifi nger, C. C., B. Linehan, and M. J. Wolin, Appl. Microbiol, 29: 480-483. 1975.

14) Latham, M. J. and M. J. Wolin, Appl. Environ. Microbiol,, 34: 297-301. 1977.

15) Chen, M. and M. J. Wolin, Appl. Environ. Microbiol., 34: 756-759. 1977. 


\title{
HiNo
}

16) Bauchop, T. and D. O. Mountfort, Appl. Environ. Microbiol, 42: 1103-1110. 1981.

17) Vogels, G. D., W. F. Hoppe, and C. K. Stumm, Appl. Environ. Microbiol., 40: 608-612. 1980.

18) Abou Akkada, A. R., E. E. Bartley, R. Berube, L. R. Fina, R. Meyer, D. Hendricks, and F. Julius, Appl. Microbiol., 16: 1475-1477. 1968.

19) Orpin, C. G., J. Appl. Bacteriol., 43: 309-318. 1977.

20) Hino, T., M. Kametaka, and M. Kandatsu, J. Gen. Appl. Microbiol., 19: 305-315. 1973.

21) Hino, T., M. Kametaka, and M. Kandatsu, J. Gen. Appl. Microbiol., 19: 315-325. 1973.

22) Hino, T., Jpn. J. Zootech. Sci., 53: 171-179. 1981.

23) Hino, T. and M. Kametaka, J. Gen. Appl. Microbiol., 33: 37-48. 1977.

24) Hino, T., M. Kametaka, and M. Kandatsu, J. Gen. Appl. Microbiol., 19: 397-413. 1973.

25) Balch, W. E., G. E. Fox, L. J. Magrum, C. R. Woese, and R. S. Wolfe, Microbiol, Rev., 43: 260296. 1979.

26) Hopner, T, and J. Knappe, in Methods of Enzymatic Analysis (Bergmyer, H. U., ed.) 15511554. Academic Press Inc., New York and London. 1971.

27) Rosenberg, J. C. and B. F. Rush, Clin. Chem., 12: 299-307. 1966.

28) Bergmeyer, H. U. and E. Bernt, in Methods of Enzymatic Analysis (Bergmeyer, H. U., ed.) 1205-1215. Academic Press Inc., New York and London. 1971.

29) Smith, P. H. and R. E. Hungate, J. Bacteriol., 75: 713-718. 1958.

30) Lindmark, D. G. and M. Müller, J. Biol. Chem., 248: 7724-7728. 1973.

31) Yarlett, N. A., A. C. Hann, D. Lloyd, and A. Williams, Biochem. J., 200: 365-372. 1981.

32) Wolin, M. J., Am. J. Clin. Nutr., 27: 1320-1328. 1974.

\section{エントディニウム属の反忽胃䋐毛虫の発酵に 及ぼす水素の影響}

\author{
日 野 常 男
}

東京大学碡学部，文宗区 113

酸素を終末電子受容体とすることができない媒気性微 生物に打いては，登醉の過程で遊離される電子の処理の

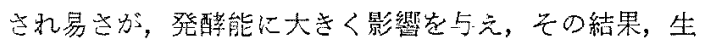

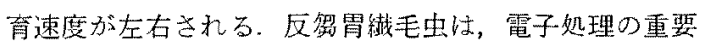
な方法として， $\mathrm{H}_{2}$ 産生与るが，この $\mathrm{H}_{2}$ 生成反心は $\mathrm{H}_{2}$ 分圧の影悡友受ける可能性があると考光られるので, この点を検剖した。

ヤギの反罗胃から採取したエントディニウム属の混合

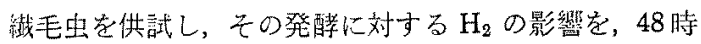
間の培養実験により調べた， $\mathrm{H}_{2}$ を連続的に通気するこ とにより， $\mathrm{H}_{2}$ 分生を高くした場合には， $\mathrm{N}_{2}$ を通気した 対照区よりも，でんら゚消惪量および総有機酸生成量ぶ 有意に娍少することが示された。また，発醉ハターンに

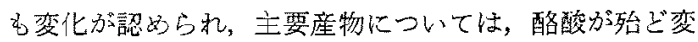
化しなかったのに対し，酶酸方顕著に娍少し，元の結 果, 生成割合では酢酸の減少, 酪酸の堌加という形之な st.

次に，繊毛虫が産生した $\mathrm{H}_{2}$ 学速やかに除去する目的 で，タン菌の其存下で培瀁を行なったところ，メタン 菌の其存区で発酝能が高くなることが示された。すなわ ち、でえぷえ消营量, 総有機酸生成量および $\mathrm{H}_{2}$ 生成量 が璔加した。この場合にも，酢酸の比率の激增と酪酸の 比率の減少という発䤃ベターンの变化が認められた。 た, 一キソース発酵量とATP 生成量の見積り值から， メタン菌の共存により，発醉能，すはわらエネルギー獲 得能力が增大することが示唆され，したがって，生育速 度も促進されるものと推測された。

しかし，全体的に，䄾毛虫に刘する $\mathrm{H}_{2}$ の影留は著し く大きいものではなかった。これらの結果について，種

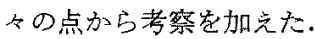

日畜会報，54（5)：320-328，1983 